\title{
Tantangan Aplikasi Sekolah Pintar di Kawasan Timur Indonesia
}

\author{
Nino Kemal Ahmad \\ Magister Ilmu Komunikasi, Graduate School, Universitas Pelita Harapan \\ Jl. Garnisun 1 No 8 Jakarta 12930 \\ nino_kemal_ahmad@yahoo.com
}

Diterima: Mei, 2019 Direview: Mei, 2019 Diterbitkan: Juni, 2019

\begin{abstract}
Abstrak. Teknologi pendidikan sebagai sarana memudahkan proses pembelajaran dilihat sebagai suatu hal yang tidak dapat dipisahkan lagi dalam kehidupan sehari-hari. Tujuan penulisan jurnal ini adalah menumbuhkan kesadaran di antara para pemangku kepentingan dan pembuat kebijakan dalam merumuskan strategi dalam formula penerapan teknologi pendidikan di Indonesia umumnya dan KTI khususnya. Metodologi yang digunakan dalam penulisan jurnal ini adalah ulasan dokumen masa lalu dan saat ini. Hasil analisis penelitian ini yaitu faktor pengajar, faktor perencanaan strategis dan faktor infrastruktur teknologi dan komunikasi. Kesimpulannya bahwa mutu pendidikan peserta didik harus ditingkatkan guna meningkatkan literasi teknologi.
\end{abstract}

Kata Kunci: Komunikasi, Teknologi, Kesenjangan Digital

Abstract. Educational technology as a means of facilitating the learning process is seen as an inseparable thing in everyday life. The purpose of this journal writing is to raise awareness among stakeholders and policy makers in formulating strategies in the formula for applying educational technology in Indonesia in general and KTI in particular. The methodology used in writing this journal is a review of past and current documents. The results of the analysis of this study are teaching factors, strategic planning factors and technological and communication infrastructure factors. The conclusion is that the education quality of students must be improved in order to improve technology literacy in Eastern Indonesia.

Keywords: Communication, Technology, Digital Divide

\section{Pendahuluan}

Permasalahan utama dalam pembangunan manusia Indonesia seutuhnya terletak pada perbedaan perlakuan pembangunan yang mengakibatkan adanya kesenjangan pembangunan antara Kawasan Barat Indonesia dengan Kawasan Timur Indonesia. Indonesia Timur meliputi provinsi-provinsi sebelah timur Republik Indonesia di Sulawesi, Maluku, Nusa Tenggara Timur, Papua Barat dan Papua (indonesiatimur.com). Kawasan Timur Indonesia yang memiliki karakteristik luas kawasan, kepadatan penduduk yang rendah, keragaman hayati dan budaya dan rendahnya tingkat penguasaan informasi dan teknologi yang mempengaruhi literasi teknologi. Kesenjangan digital dalam aspek pendidikan menjadi pokok permasalahan dalam tulisan ini. Data mengenai peran teknologi pendidikan dalam proses belajar mengajar dan hubungannya dengan kesenjangan digital yang terjadi di Kawasan Timur Indonesia akan disajikan dalam tulisan ini. Di balik informasi ini, sebuah pekerjaan rumah menjadi refleksi para pemangku kepentingan dan pembuat kebijakan dalam merumuskan formula mengatasi kesenjangan digital.

Data terbaru menunjukan bahwa kawasan Indonesia Timur mengalami pertumbuhan pengguna internet yang signifikan dan tercatat sebagai pertumbuhan pengguna tertinggi dibanding kawasan lain di Indonesia. Sulawesi Utara misalnya, provinsi yang 

mengalami peningkatan tertinggi dalam penggunaan komputer dan internet dalam aktivitas bisnis. Namun, provinsi Maluku menjadi tempat bagi penggunaan internet terendah di KTI (http://www.koranjakarta.com, Pengguna Internet di Kawasan Indonesia Timur Melesat, 20 Februari 2014). Hasil Survei yang dilakukan Data Asosiasi Penyelenggara Jasa Internet Indonesia (APJII) bekerjasama dengan Badan Pusat Statistik (BPS) menyebutkan di Maluku Utara dan Papua Barat, kurang dari sepertiga jumlah responden telah menggunakan internet. Perbandingan kesenjangan penggunaan internet ini terlihat dari wilayah perkotaan dan pedesaan. Di daerah perkotaan hanya $13 \%$ dari anak dan remaja yang tidak menggunakan internet, sementara daerah perdesaan menyumbang jumlah $87 \%$. Pengguna internet lebih banyak terpusat di Daerah Istimewa Yogyakarta, Jakarta, dan Banten. Oleh karena itu, artikel ini mendiskusikan "Bagaimana faktor kesenjangan digital mempengaruhi aplikasi teknologi pendidikan di KTI?"

\section{Kajian Literatur}

Teknologi identik dengan perubahan sosial. Perubahan sosial yang sifatnya progresif nyaris tidak terlepas dari modernitas. Seperti yang penulis sudah jelaskan sebelumnya, bahwa peradaban manusia saat ini telah tiba dalam satu tahapan peradaban baru, yaitu masyarakat informasi (information society) yang didefinisikan sebagai masyarakat yang menerima, mengolah dan menyimpan informasi dan pengetahuan serta menjadi elemen dasar penggerak berbagai institusi sosial dan, utamanya, institusi ekonomi yang mempengaruhi kehidupan masyarakat sehari-hari.
Carey (1989) juga menegaskan ciri masyarakat informasi ini bahwa teknologi menciptakan 'futurist ethos' atau secara harfiah berarti 'etos masa depan' yang diidentifikasi oleh perangkat elektronik, computer dan informasi sebagai cikal bakal lahirnya bentuk komunitas baru, kesinambungan lingkungan dan harmoni sosial (Carey, 1989).

$$
\text { Menurut Daniel Bell (1977) }
$$

masyarakat pasca industri atau yang dikenal sebagai masyarakat informasi yang ditandai dengan karakteristik semakin majunya teknologi mikrocip komputer. Era yang dikenal juga sebagai revolusi teknologi dimana peran besar teknologi mengatasi ruang dan waktu (Negroponte, 1995). Era teknologi ini berangkat dari arus informasi, pengetahuan dan jasa. Kehidupan masyarakat pasca industri ini juga ditandai dengan kualitas kehidupan yang diukur dengan jasa dan kesejahteraan-kesehatan, pendidikan, rekreasi dan seni-yang sekarang menjadi tujuan dan cita-cita semua orang. Kemajuan teknologi mempengaruhi seluruh aspek kehidupan manusia. Thomas Friedman dalam bukunya, The World is Flat secara garis besar menceritakan sejarah singkat abad 21 yang fokus pada globalisasi. Dunia yang 'datar'. Friedman memulai dengan pernyataan "I think the world is flat". 'Dunia yang datar' karena berubah. Dunia, yang kita tempati sekarang, adalah pijakan untuk melihat perubahan hampir di seluruh aspek kehidupan. Akibat dari globalisasi yang mempengaruhi aktivitas ekonomi, komunikasi, politik, sosial maupun budaya. Seperti yang disebutkan Pacey bahwa teknologi memainkan peranan penting dalam peradaban (Pacey, 2013). 


\subsection{Teknologi dalam Pendidikan}

Bidang pendidikan yang termasuk sektor jasa dan pelayanan juga mau tidak mau terpengaruh oeh teknologi. Teknologi pendidikan tepatnya. Teknologi pendidikan dapat didefinisikan sebagai 'kajian untuk membantu proses belajar dan meningkatkan kinerja dengan membuat, menggunakan dan mengelola sumber informasi' (Seels \& Richey, 1994). Reflections on the 2008 AECT Definitions of the Field. TechTrends. 52 24-25). Aplikasi teknologi dalam pendidikan bisa dilihat dalam bentuk 'smart school'. 'Smart School' atau Sekolah Pintar merupakan suatu konsep sekolah yang berbasis teknologi yang digunakan dalam proses belajar-mengajar di kelas. Penggunaan teknologi pendidikan mencakup suatu sistem terintegrasi yang membantu komunitas pendidikan dalam menjalankan fungsinya masing-masing dengan tujuan mengembangkan potensi peserta didik.

$$
\text { Pada dasarnya, penggunaan }
$$
teknologi dalam bidang pendidikan adalah untuk membantu proses belajar dan meningkatkan kinerja dengan membuat, menggunakan, dan mengelola proses dan sumber teknologi yang memadai. Sedangkan tujuan utama teknologi dalam pembelajaran adalah (1) untuk memecahkan masalah belajar atau memfasilitasi pembelajaran; dan (2) untuk meningkatkan kinerja (Iswanto, 2018).

Penggunaan teknologi berbasis internet dalam bidang pendidikan ini membantu interaksi antara komunitas sekolah, siswa dan guru misalnya semakin lebih mudah. Di sini peran guru bukan lagi sebagai sumber informasi satu-satumya namun lebih kepada fasilitator yang memfasilitasi peserta didik dalam mengembangkan kemampuan kognitif, afektif maupun psikomotoriknya.
Namun, penerapan teknologi pendidikan di Indonesia belum berimbang antara Kawasan Barat Indonesia (KBI) dan Kawasan Timur Indonesia (KTI). Sumber daya alam (SDA) yang melimpah dan wilayah yang potensial untuk menjadi kekuatan ekonomi berbasis maritim menjadi karakteristik unggulan KTI. Kelemahannya dapat terlihat dari sumberdaya manusia yang sangat terbatas secara kualitas maupun kuantitas. Kebijakan pembangunan di KTI yang masih belum sepenuhnya menempatkan sumber daya manusia sebagai target dan basis pembangunan bercirikan human development (pembangunan manusia), yaitu sebuah pembangunan yang berorientasi pada manusia (people center development), di mana manusia dilihat sebagai target sekaligus sebagai pelaku pembangunan menjadi kontraproduktif dengan kebijakan pembangunan KTI masih berorientasi pada pertumbuhan ekonomi dengan penggalakan investasi besarbesaran (Ariani, Enny. Potret Ketertinggalan Sumber Daya Manusia di Kawasan Indonesia Timur, bto.depnakertrans.go.id). Investasi ini juga tidak dibarengi oleh pembangunan infrastruktur telekomunikasi yang memadai dan akhirnya melahirkan jurang kelas baru dalam konteks teknologi.

Fungsi teknologi pendidikan pada dasarnya adalah sebuah proses dan bukan berorientasi pada hasil akhir. Teguh Santoso (2007) mengatakan bahwa teknologi informasi komunikasi merupakan segala bentuk teknologi yang mendukung penyampaian informasi dan pelaksanaan proses komunikasi. Teknologi ini mencakup penggunaan media massa dalam prakteknya, seperti radio, televisi maupun internet. Teknologi informasi komunikasi dalam dunia pendidikan digunakan untuk 
belajar jarak jauh (distance learning) mengatasi ruang dan waktu. Dan di era cyber ini sudah menjadi pemandangan biasa jika teknologi ini digunakan untuk membantu proses belajar secara elektronik (electronic learning/e-electronic) dengan menggunakan fasilitas internet (Mirabito \& Morgenstern, 2004)

Penggunaan teknologi dalam bidang pendidikan sudah menjadi trend saat ini. Hal ini tidak dapat dihindari mengingat seperti yang sudah disebutkan sebelumnya bahwa teknologi sudah mempengaruhi tiap aspek kehidupan manusia. Dalam proses belajar mengajar, instruksi berbasis multimedia dapat menjadi contoh dari terintegrasinya beberapa media yang berbeda ke dalam satu platform interaktif yang memuat beragam konten text, gambar, animasi, suara maupun video (Ann, 2002)., Technologies for Education: A Practical Guide, Libraries Unlimite. Terintegrasinya media yang berbeda platform merupakan bentuk dari Media Baru yang didefinisikan sebagai bentuk komunikasi media massa yang menggunakan perangkat elektronik, seperti Internet, CD-ROM, World Wide $W e b$, video games, media interaktif dan lain sebagainya yang mulai populer di era 1990an. Selain itu contoh lainnya seperti feeds, blog, podcasts, voice over internet protocol maupun portal komunitas seperti Facebook, Myspace atau Linkedin dan Youtube. Media Baru mengacu pada media massa yang berbasis teknologi informasi, digital dan melibatkan jaringan komunikasi baru - internet (Straubhaar, LaRose, \& Davenport, 2012).

Media Baru ini ditandai dengan adanya konvergensi media dan tingkat partisipasi yang tinggi. Konvergensi media merujuk pada 'One Screen' dimana lewat satu layar terdapat platform media yang berbeda-beda (Greensdale, 2006). 'Media baru'- yang juga dikenal dengan second media age - memiliki karakteristik tingginya volume interaksi, kebebasan bicara (freedom of speech), virtual assembly' untuk diskusi kelompok yang difasilitasi komputer dan pertukaran informasi yang mengandalkan multiple source (Holmes et al (2012)., Australian Sociology: A Changing Society). Konvergensi media atau media convergence- penggabungan media berbasis tiga industri yang berbeda: telekomunikasi, komputasi dan elektronik atau broadcasting) - membawa pengaruh di bidang pendidikan. Program multimedia membuka peluang peserta didik untuk berinteraksi, menciptakan sesuatu maupun berkomunikasi satu sama lain dalam bentuk virtual. Jaringan komputer yang terkoneksi secara terintegrasi menggunakan teknologi wireless maupun sistem sambungan telepon, satelit atau gelombang radio menunjang proses komunikasi maupun aktivitas riset di dalam maupun di luar ruang kelas (Mirabito \& Morgenstern, 2004).

Perkembangan teknologi yang cepat dan semakin ringkas dan praktis didukung oleh perangkat software dan hardware yang semakin terjangkau. Laptop, smartphone atau telepon pintar dan modem untuk terkoneksi dengan jaringan internet dapat dimiliki dengan harga yang relatif murah (Widiastuti \& Ruliana, 2017). Smartphone mendukung layanan multimedia seperti MMS (multimedia message service), akses internet, komunikasi wireless jarak pendek (bluetooth), gaming, fotografi, video maupun musik. Penggunaan telepon pintar ini meningkat secara signifikan dan mendekati $90 \%$ dari total populasi global di tahun 2012. Melalui smartphone peserta 
didik murid dan guru bisa mengakses $e$ mail untuk mengirimkan dan memeriksa tugas. Seperti yang diprediksi Laura Lindhe dari CNET (The Computer Network), "In the nearfuture, your phone will be a multifunctional device-you'll be able to videoconference, play games, browse the web, and listen to music. In 10 years, the phone will be as small as a watch and you'll just use headphones to attach to it." (Lindhe, 1999).

Terdapat dua jenis cara pembelajaran yang sudah dikenal sebelumnya, independent learning, dimana siswa belajar sendiri dengan buku, dan interactive learning yang melibatkan orang lain (Daniel \& Marquis, (1979) dalam (Daniel, 2010). Bates kemudian menambahkan perbedaan interaksi antara individu dan materi yang dipelajari. Pertama, individu yang mengisolasi dirinya dimana interaksi terjadi antara individu tadi dengan materi pembelajaran yang dapat berupa text, televisi atau komputer program. Kedua, interaktif dalam konteks aktivitas sosial, dimana proses pembelajaran mencakup interaksi yang berlangsung antara dua orang atau lebih dengan menggunakan komputer sebagai alat belajar" (Bates, (1995)., dalam (Daniel, 2010) Dalam konteks interaktif, media sosial menjadi sarana dalam proses pembelajaran. Media sosial memungkinkan adanya komunikasi interaktif antara guru dan murid atau antara murid dengan murid yang lebih cocok dikategorikan dengan tipe kedua Bates tadi. Sejak kata 'interaktif' memiliki arti luas, Mason menegaskan bahwa proses komunikasi antara dua orang atau lebih harus memiliki 'feedback' atau umpan balik dalam konteks human response - tertulis atau tidak tertulis.

\subsection{Ranah Teknologi Pendidikan}

Mirabito dan Morgenstern (2004) merumuskan lima aspek teknologi yang mencakup proses pembelajaran, yaitu : Desain, pengembangan, pemanfaatan, pengelolaan, dan penilaian. Kelima aspek ini bersifat saling melengkapi. Hal ini akan dibahas lebih lanjut di manfaat teknologi dalam pendidikan. Pembangunan pendidikan berbasis IT setidaknya memberikan dua keuntungan. Pertama, sebagai pendorong komunitas pendidikan (termasuk guru) untuk lebih apresiatif dan proaktif dalam maksimalisasi potensi pendidikan. Kedua, memberikan kesempatan luas kepada peserta didik memanfaatkan setiap potensi yang ada dapat diperoleh dari sumber-sumber yang tidak terbatas.

Bagian ini akan menjelaskan penerapan teknologi pendidikan mencakup lima ranah yang berbeda, yaitu : Desain, pengembangan, pemanfaatan, pengelolaan, dan penilaian.

\section{Desain kurikulum}

Guru dapat mendesain kurikulum secara online dengan bantuan internet. Australian Capital Teritory misalnya. Kurikulum yang diterapkan di Sekolah Cita Buana Jakarta ini berasal dari Australia dan memberikan kesempatan kepada guru untuk mengakses secara online konten kurikulum maupun sumber referensi untuk pengembangan kurikulum itu sendiri. Framework atau desain kurikulum yang sudah dirancang sebelumnya dapat dimodifikasi menurut kebutuhan siswa dan sekolah. Website ACT kurikulum ini juga memberikan kesempatan kepada guru untuk berinteraksi secara online lewat chat room. Dengan begitu guru dapat bertukar pengalaman maupun informasi untuk menyempurnakan kurikulum. Penyajian kurikulum kepada siswa juga lebih menarik 
dibandingkan dengan menggunakan media cetak.

2. Pengembangan materi ajar

Informasi yang ada di internet menjadi lebih mudah diakses dan lebih cepat ditransmisikan dari satu media ke media lainnya. Internet membantu guru dalam mengembangkan materi ajar. Misalnya, ketika belajar tentang Apartheid di mata pelajaran Ilmu Pendidikan Sosial tersedia resources yang melimpah sebagai bahan ajar guru. Dari desain worksheet atau lembar kerja, instruksi pembuatan portfolio sampai soal-soal latihan untuk final exam tersedia di internet. Hanya saja, guru dan murid dituntut memiliki research skill yang baik. Kemampuan mengakses internet ada baiknya dibarengi dengan kemampuan menyeleksi, memfilter, menganalisa maupun mengorganisasi informasi yang sifatnya multidimensional. Ini merupakan ciri higher order thinking skills (HOTS). Kegunaan Internet dalam proses belajar mengajar bergantung pada cara penggunaannya. Namun, penggunaan konten multimedia yang cenderung untuk meningkatkan kemampuan berpikir kritis siswa tidak dibarengi dengan ketersediaan sumber informasi (Ann, 2002).

3. Pemanfaatan teknologi

Kalkulator grafis misalnya, yang merupakan representasi simbol matematika dapat membantu siswa untuk mengerti tujuan pembelajaran selain mudah diakses siswa. Simulasi membuat konsep yang sifatnya abstrak, seperti pecahan dapat terlihat jelas oleh siswa dalam mengaplikasikan ide utama pembelajaran. Online educational projects, seperti I*EARN, membantu siswa dan guru dalam bekerjasama - collaborative learners dalam membangun kebersamaan dan meningkatkan rasa hormat terhadap budaya satu dengan yang lain (Ashburn \& Floden, 2006). Penggunaan perangkat software seperti Prezi yang tersedia sebagai opensource juga membantu siswa dalam melakukan persentasi dan memampukan mereka bekerjasama dalam kelompok dan mengkombinasikan form yang berbeda (baca: konvergensi media) dalam menciptakan suatu produk. E-mail, bukan menjadi barang baru lagi. Guru dan siswa dapat berinteraksi 24 jam menggunakan $e$ mail. Selain e-mail, media sosial, seperti Whatsapp, Facebook, Line maupun Twitter semakin mempermudah proses komunikasi dan pertukaran informasi antara guru dan siswa.

Blog juga dapat diberdayakan sebagai sarana pembelajaran. Seperti yang dilakukan di Sekolah Cita Buana dalam pelajaran sosiologi. Guru mengadakan video-conference dengan salah satu sekolah di India dan Bandung tentang multikulturalisme. Siswa kemudian diminta untuk menulis refleksi di blog Face To Faith.org dimana siswa dari belahan dunia lain dapat menikmati tulisan refleksi tersebut. E-learning dapat juga dilakukan untuk menunjang pembelajaran jarak jauh Courses through distance learning. Seperti yang terdapat di website coursera.org dimana peserta didik dapat mengakses pendidikan jarak jauh dengan mengambil mata kuliah yang diinginkan dan akan mengerjakan ujian dan jika lulus akan mendapatkan sertifikat kelulusan seperti lembaga pendidikan pada umumnya. Coursera yang bekerjasama dengan beberapa universitas terkemuka di sejumlah negara menawarkan kursus online secara cuma-cuma. Kursus online sifatnya fleksibel karena disesuaikan dengan waktu mahasiswa. Meski begitu, seperti kuliah sungguhan, para mahasiswa diberi materi, 
rekomendasi bacaan, mendengarkan dosen menjelaskan via video, dan memiliki jadwal ujian khusus. Hingga saat ini Indonesia sudah memiliki Undang-undang No. 20 Tahun 2003 tentang Sistem Pendidikan Nasional pasal 31 dan SK Mendiknas No. 107/U/2001 tentang PTJJ. Di mana secara lebih spesifik UU ini mengizinkan penyelenggara pendidikan di Indonesia untuk melaksanakan pendidikan melalui cara PTJJ dengan memanfaatkan teknologi informasi (Konstitusi, 2003).

Fenomena lain dalam penggunaan teknologi dalam pendidikan adalah $e$-book. Di tahun 2000an, para penerbit tertarik dengan e-book (singkatan dari electronic book) yang dikenal dengan buku digital. Bentuknya bisa bermacam-macam, seperti file pdf, word, html, txt dll. Sampai dengan tahun 2007, e-book dibaca dengan menggunakan perangkat komputer tidak digunakan secara terpisah dengan $e$ readernya. Namun, saat ini e-book bisa dinikmati melalui tablet atau smartphone yang memiliki kemampuan mengunduh aplikasi e-readernya secara portable. Banyak manfaat yang didapatkan dari $e$ book ini, seperti kemudahan menyimpan buku, bagi para penulis, bisa menerbitkan tulisannya tanpa bantuan penerbit. Selain itu, dengan adanya e-book ini diharapkan menjadi salah satu cara mencari informasi di internet. Penggunaan $e$-book ini sangat digemari masyarakat urban atau modern yang tidak lepas dari gaya hidup. Perbedaan buku digital dan buku cetak sangat jelas. Buku cetak memerlukan kertas sebagai material dasarnya. Sedangkan buku digital atau $e$-book sifatnya paperless artinya tidak menggunakan kertas. Selain itu, e-book dapat berfungsi hanya dengan energi listrik. Artinya, ketergantungan terhadap kertas dapat dikurangi. E-book ini juga dapat menjadi sarana bagi orang tua untuk menceritakan dongeng sebelum tidur maupun cerita rakyat (folklor) kepada anakanaknya. Seperti yang dilakukan sebuah situs, Qbaca, sebuah konten lokal yang diprakarsai oleh PT Telkom (Kompas.com, 10 Maret 2014).

\section{Pengelolaan}

Cloud Computing atau komputasi awan dapat diterapkan misalnya untuk $e$ library. Katalog buku, bibliografi, administrasi, file digital maupun akses perpustakaan dapat disimpan di komputasi awan. Dalam konteks konten koleksi buku, jurnal berlangganan maupun penerbitan juga dapat memanfaatkan komputasi awan tersebut selain menyimpan data riset. Penggunaan teknologi dalam konsep sekolah pintar juga dapat terlihat dari beberapa hal. Dari sisi guru, pengelolaan administrasi lebih mudah dilakukan. Misalnya, penulisan, penyusunan maupun perencanaan rencana pembelajaran dapat dibandingkan dengan rencana pembelajaran guru-guru lain yang tergabung dalam komunitas pendidikan.

Administrasi nilai maupun rapot sekolah dapat dilakukan dengan memanfaatkan OneDrive (nama resmi Microsoft OneDrive) yang merupakan layanan komputasi awan serupa dengan Dropbox dan Google Drive yang memungkinkan penggunanya mengunggah dan mensinkronkan berkas ke suatu penyimpanan awan dan kemudian mengaksesnya melalui peramban web tertentu. Setiap guru akan mendapatkan akun user dan password. Setelah membuka situs www.onedrive.com terdapat dua folder yaitu Document dan Pictures dimana guru bisa menyimpan file-file secara gratis dengan kapasitas sebesar 15GB. Untuk membuka file Raport Sekolah Cita Buana misalnya, guru mengklik Shared dan Master Raport Sekolah Cita Buana 2014- 
2015, pilih kelas yang ingin diedit/masukan nilai dan siap untuk editing atau olah nilai. Semua data yang diedit otomatis akan tersimpan.

\section{Penilaian}

Memasukan nilai siswa juga bisa dilakukan secara online dan data tiap guru dapat disimpan di server sekolah dengan menggunakan jaringan LAN. Teknologi berbasis internet juga dapat digunakan dalam membangun media komunikasi sekolah. Informasi dan sosialisasi program sekolah ke pihak orang tua dapat dilakukan lewat website. Begitu juga dengan agenda online siswa yang dapat diakses melalui multi platform.

\subsection{Kesenjangan Digital atau Digital Divide}

Kendala utama dalam aplikasi sekolah pintar di Indonesia terletak pada kesenjangan digital atau digital divide antara KBI dan KTI. Istilah kesenjangan digital merujuk pada satu istilah yang menggambarkan adanya kesenjangan penggunaan teknologi internet antara si kaya dan si miskin, antara kulit putih dan kaum minoritas (Straubhaar et al., 2012). Definisi kesenjangan digital menurut OECD (Organization for Economic CoOperation and Development ) tahun 2001, yaitu suatu gap/kesenjangan antar individu, kelompok, bisnis, dan area geografis pada level sosial-ekonomi yang berbeda, dimana sangat membutuhkan akses teknologi informasi dan komunikasi serta penggunaan internet untuk berbagai aktivitas kehidupan. Istilah ini juga menciptakan jurang kelas baru yang terjadi pada masyarakat kelas bawah, yang tidak dapat menikmati akses dan layanan internet.
Di seluruh dunia kesenjangan digital dapat dilihat di negara-negara berkembang. Penduduk pedesaan, kelompok minoritas dan kelompok penduduk yang memiliki pendapatan rendah adalah mereka yang paling minim mendapat exposure teknologi ini (Richard, 2012). Menurut data Internet World Statistics (2009), dua puluh negara teratas pengguna internet menyumbang $76.8 \%$ pengguna internet dari seluruh dunia dimana negara-negara tersebut lebih banyak didominasi negara maju. Hal ini juga menunjukan bahwa tiga dari empat orang di dunia tidak memiliki akses internet. Pemisahan digital ini menjadi parameter yang memisahkan antara kaum tak berpunya (the have not) dan kaum berpunya (the haves) (Green, 2010). Kesenjangan digital di Indonesia dapat dilihat dari terkonsentrasinya penggunaan teknologi berbasis internet di pulau Jawa, terutama di kota-kota besar. Daerah tertinggal atau pulau-pulau yang jauh, sayangnya, belum mendapatkan akses internet. Berdasarkan data 2007, penduduk Indonesia yang memiliki akses internet hanya $2 \%$ dari jumlah populasi. Bandingkan misalnya dengan Singapura, yang berada di kisaran 76\% (Jakarta Globe, 6 Januari 2012). Gambaran kesenjangan digital antara KBI dan KTI dapat dilihat dari disparitas ekonomi antar Kawasan Barat dan Kawasan Timur Indonesia, yang ditunjukan dengan kontribusi Pendapatan Domestik Regional Bruto (PDRB) SeSulawesi-Maluku dan Papua (SeSulampua) terhadap PDRB Nasional, yang hanya berada pada kisaran 7\%, jauh lebih kecil dibanding PDRB Kawasan Barat yang mencapai sekitar 58\%. (kabarbisnis.com). Hasil riset ITU (International Telecommunication Unit), Â The Impact of 
Broadband on the Economy : Research to

Date and Issues, juga menunjukkan, di negara-negara dengan pendapatan masyarakat yang masih dalam skala menengah, peningkatan penetrasi broadband internet sebesar $10 \%$ akan mendongkrak pertumbuhan Produk Domestik Bruto (PDB) sebesar 1,38\%.

Kesenjangan digital menjadi perhatian penting di berbagai negara untuk mewujudkan pemerataan pembangunan di bidang teknologi informasi, salah satunya yaitu di Indonesia. Data Asosiasi Pengusaha Komputer Indonesia (APKOMINDO), menyatakan bahwa penetrasi komputer di Indonesia baru $4 \%$ dari populasi penduduk atau sekitar 9,2 juta unit. Jika dibandingkan dengan kondisi beberapa negara di ASEAN maka tingkat kepemilikan komputer rata-rata mencapai $30 \%$ dari jumlah penduduk. India misalnya, meski tingkat kepemilikan komputer hanya 12 unit per 1000 penduduk (atau hanya $0,12 \%$ ) namun lapangan kerja dalam bidang IT telah mampu menyedot lebih dari 500.000 pekerja professional (Pikiran Rakyat Online, 28/7/2011). Artinya, selain tingkat pendidikan, kesenjangan digital tidak hanya dipengaruhi oleh tinggirendahnya tingkat kepemilikan komputer, tetapi juga tingkat penguasaan dan pemanfaatan teknologi informasi maupun pengetahuan masyarakat akan teknologi informasi. Kesenjangan digital menciptakan masyarakat gagap teknologi. Rendahnya tingkat pendidikan khususnya angkatan kerja di KTI mayoritas masih didominasi oleh penduduk yang memiliki pendidikan SD kebawah, dan sekitar $38 \%$ mempunyai pendidikan yang dikelompokkan sebagai pendidikan menengah (SMTP, SMTA dan Diploma 1 dan 2), sedangkan sisanya hanya sekitar $2 \%$ mempunyai tingkat pendidikan relatif tinggi (Akademi dan Perguruan Tinggi) (Ariani, Enny: 4). Selain tidak paham teknologi informasi, mereka juga tidak dapat menggunakan fasilitas yang ada ditambah infrastruktur yang belum memadai. Internet bagi mereka seperti barang asing dibandingkan dengan media lain seperti radio dan tv.

Berikut adalah kerangka teori yang digunakan :

Teori Difusi Inovasi

Inovasi yang menjadi pembahasan Rogers dalam teori ini dikomunikasikan kepada sekelompok anggota dari sistem sosial melalui saluran-saluran tertentu sepanjang waktu (Rogers, 2003). Sedangkan 'difusi' diartikan sebagai gagasan atau ide baru yang penyebaran pesannya dilakukan melalui suatu bentuk komunikasi yang bersifat khusus. Dalam proses difusi inovasi ini terdapat empat (4) elemen pokok, yaitu:

(1) Inovasi; gagasan, tindakan, atau objek (produk barang) yang dianggap baru oleh seseorang,

(2) Saluran komunikasi; individu menciptakan atau berbagi pengalaman dengan yang lain menggunakan 'saluran' untuk menyampaikan pesan-pesan inovasi dari sumber kepada penerima,

(3) Jangka waktu; proses keputusan inovasi, dari mulai seseorang mengetahui sampai memutuskan untuk menerima atau menolaknya,

(4) Sistem sosial; kumpulan unit yang berbeda secara fungsional dan terikat dalam kerjasama untuk memecahkan masalah dalam rangka mencapai tujuan bersama (Rogers, 2003).

Perspektif Payung Grant 
Untuk memahami fenomena ini kita dapat menggunakan Perspektif Payung Grant (August, 2008). Perspektif Payung Grant mengatakan bahwa untuk mengembangkan teknologi baru diperlukan pengembangan perangkat keras (hardware). Selain itu, message atau pesan - yang terdapat dalam software melengkapi sistem teknologi tersebut. Software dalam konteks ini bukan hanya diartikan sebagai aplikasi komputer tetapi juga merujuk pada pesan atau informasi yang dimanipulasi oleh komputer. Misalnya, text, lembar kerja atau jenis pekerjaan lainnya yang dilakukan perangkat komputer.

Dari personal atau individual user (pengguna pribadi), menurut Perspektif Grant, kemudian mempengaruhi organisasi dimana para individual user ini berkumpul atau bekerja. Dari organisasi maupun perusahaan ini maka sistem teknologi ini kemudian berperan besar terhadap sistem sosial masyarakat yang lebih besar, seperti politik, ekonomi, sosial dan budaya. Perspektif payung Grant dapat menjelaskan konsep sekolah pintar ini dimana penggunaan software dan hardware komputer oleh pengguna pribadi membentuk kelompok individu yang melayani kepentingan masyarakat. Sekolah, sebagai salah satu institusi sosial, juga terpengaruh oleh perkembangan teknologi dan informasi. Organisasi ini kemudian yang membentuk sistem informasi dan komunikasi di masyarakat. Perspektif ini merupakan sintesa dari Rogers (2003) yang mendefinisikan teknologi komunikasi sebagai struktur organisasi dan kumpulan nilai-nilai masyarakat berbasis perangkat keras di mana individu saling mengumpulkan, memproses dan menukar informasi. Beberapa faktor yang menentukan penerapan teknologi komunikasi adalah faktor enabling, faktor limiting , faktor motivating dan faktor inhibiting.

\section{Computer Mediated Communication}

Stephens (2007) menekankan pada pendekatan informasi dan teknologi (ICTs) dalam teorinya bahwa pengiriman pesan dapat dilakukan melalui saluran komunikasi yang beragam (Stephens, 2007). Pendekatan ICT ini dapat digunakan dalam bentuk yang berbeda, seperti media tradisional maupun saluran tatap muka. Kombinasi dari penggunaan saluran yang beragam dapat meningkatkan efektivitas komunikasi dalam organisasi, termasuk sekolah.

Ia juga menekankan bahwa pengulangan pesan melalui lebih dari satu saluran komunikasi untuk beberapa tugas tertentu menyebabkan efektivitas dan efisiensi proses komunikasi. Misalnya, pesan yang disampaikan dalam sebuah pertemuan tatap muka dan kemudian dikirimkan melalui e-mail, atau sebaliknya, akan jauh lebih efektif dibanding pesan yang dikirimkan melalui satu medium saja. Artinya, komunikator dapat mengirimkan pesan lebih dari satu kali. Pendekatan ini juga mengklasifikasikan saluran dalam beberapa bentuk: tatap muka, media massa, media oral maupun textual (Stephens \& Rains, 2011).

\section{Metode Penelitian}

Metodologi yang digunakan dalam penulisan jurnal ini adalah ulasan dokumen masa lalu dan saat ini. Analisa penelitian yang sudah ada sebelumnya dalam bentuk bahan bacaan (misalnya koran, catatan artikel, penelitian ilmiah maupun dokumen lainnya) diharapkan bisa mengembangkan atau mendukung teori yang sudah ada. 
Sumber yang ada mengacu pada data yang telah dikumpulkan oleh peneliti sebelumnya dan tersedia guna kelanjutan penelitian di masa mendatang.

\section{Hasil dan Diskusi}

Beberapa faktor kendala penerapan teknologi informasi di pendidikan di KTI antara lain factor (1) pengajar/guru, (2) perencanaan strategis dan (3) infrastruktur komunikasi dan teknologi.

Masih ada anggapan bahwa yang perbedaan konsep penggunaan teknologi oleh guru karena beberapa hal (Ashburn \& Floden, 2006) yaitu mengetahui cara menggunakan komputer bukan berarti tahu bagaimana mengajar dengan komputer. Guru terkadang lebih menguasai komputer untuk melakukan pekerjaannya sendiri dibandingkan dengan penggunaan komputer. Pekerjaan itu lebih yang sifatnya administratif, seperti memasukan nilai siswa mengunakan program excel, menyusun rencana pembelajaran dengan ms word maupun melakukan presentasi sederhana dengan microsoft powerpoint. Survey yang dilakukan oleh Office of Technology Assessment seperti yang dikutip (Santrock, 2006), menemukan bahwa mayoritas guru tidak akrab dengan komputer.

Proses pembelajaran yang dilakukan di kelas dengan guru yang sudah diberi pelatihan komputer terbentur software yang tidak tersedia di sekolah. Minimnya pengetahuan yang memadai dalam menggunakan komputer tidak dibarengi dengan upaya pihak sekolah dalam menyediakan workshop atau pelatihan yang dibutuhkan. Belum lagi ketersediaan sarana komputer yang ketinggalan zaman dan belum semua sekolah difasilitasi koneksi internet.
Guru tidak perlu mengetahui teknologi secara keseluruhan. Cukup dengan kebutuhan mereka yang disesuaikan dengan kurikulum yang nantinya akan diimplementasikan di dalam kelas. Generasi tua menolak dengan alasan tidak paham/sulit/tidak mau belajar, atau belum terbiasa dengan sistem e-learning dan $e$-assessment adalah contoh tantangan dalam membangun konsep sekolah pintar ini. Anggapan yang mengatakan bahwa mengajar dengan menggunakan teknologi adalah time-consuming dan relatif sulit. Selain itu juga persiapan dalam pengajaran berbasis teknologi di kelas juga tidak mudah.

Ashburn juga berpendapat bahwa guru dan siswa harus bekerjasama dengan baik agar proses pembelajaran integratif berbasis internet dapat direalisasikan. Teknologi tidak dapat berdiri sendiri. Interaksi antara murid dan guru mutlak diperlukan agar pembelajaran berbasis teknologi dapat diaplikasikan. Pada dasarnya, guru perlu mencoba dan berlatih terus menggunakan teknologi. Kebiasaan menggunakan teknologi dalam mengajar perlu dikembangkan sehingga menjadi sebuah rutinitas. Namun, karena berbagai faktor, tidak banyak guru yang mendapatkan kesempatan ini. Berhubung sifat teknologi yang selalu berubah dengan cepat, guru dituntut untuk tetap up to date dengan teknologi, baik secara kognitif maupun praktek. Guru yang melek teknologi, dukungan sarana dan prasarana sekolah yang memadai serta lingkungan sekolah yang technology friendly diharapkan membawa perubahan positif di masa depan dalam konteks penggunaan teknologi untuk pendidikan.

Marwan \& Sweeney menyimpulkan bahwa berhasil tidaknya integrasi 
teknologi pendidikan dalam kegiatan belajar mengajar dipengaruhi oleh berbagai faktor, yaitu rasa memiliki dan sumberdaya yang ada dan dibarengi dengan pengembangan profesional. Beberapa faktor yang mempengaruhi individu dalam menyikapi penggunaan teknologi yaitu keterbukaan terhadap teknologi, sikap guru, pengetahuan dan ketrampilan, dan waktu dan beban kerja guru. Jika salah satu faktor ini tidak mendukung atau tidak berjalan dengan baik maka berpotensi menghambat integrasi pembelajaran (Marwan \& Sweeney, 2010).

Sandholtz et al. (1997) mengelompokan tahapan dimana guru mulai menerima, mengadopsi dan mengimplementasikan teknologi: (1) entry: pengenalan dan pengamatan terhadap TIK; (2) Adoption: mulai menggunakan TIK dengan bantuan, dukungan dan pelatihan; (3) Adaptation: menggunakan TIK bukan hanya untuk personal bussiness tetapi lebih luas untuk mendesain kurikulum, observasi kelas dll; (4) Appropriation: pengembangan kurikulum antar-sekolah, peer-assessment dan video conference; dan (5) Invention: mengembangkan riset sederhana, menjadi mentor bagi guru lain dan berkolaborasi dengan guru lainnya.

Faktor perencanaan strategis sebagai contoh, program Smart School di Malaysia perlu waktu untuk diimplementasikan sehubungan dengan proses sosialisasi di kalangan birokrasi dan perencanaan strategis departemen yang bersangkutan (Bajunid, 2008 ). Karakteristik lain yang menentukan suksesnya program Smart School di Malaysia adalah faktor kepala sekolah yang berkualitas (Puteh dan Vicziany, 2004).

Terakhir, faktor infrastruktur komunikasi dan teknologi. Selain faktor guru, kurangnya pengadaan dan pembangunan infrastruktur teknologi komunikasi disebabkan sulit dijangkaunya beberapa daerah tertentu di Indonesia, terutama di KTI, sehingga penyebarannya tidak merata. Faktor geografis masih menjadi tantangan utama dalam pembangunan infrastruktur. Anggaran Kemendikbud tahun 2011 hanya bisa menjangkau sekitar 27.000 sekolah dari total 270.000 sekolah di Indonesia. Ketiadaan jaringan listrik menjadi masalah utama. Listrik yang digunakan hanya untuk penerangan bukan untuk kegiatan belajar mengajar. Jika menggunakan jaringan internet satelit harganya mahal (Kompas, 22 November 2014). Saat ini, dengan dukungan daerah, fasilitas jaringan internet sudah menjangkau 100.277 sekolah yang mayoritas SMA/SMK.

\section{Simpulan}

Mutu pendidikan peserta didik, baik siswa maupun guru, harus ditingkatkan guna meningkatkan literasi teknologi di KTI. Pemerintah daerah harus memiliki inisiatif dan komitmen tinggi dalam mendorong pembangunan infrastruktur teknologi informasi di daerahnya. Kesenjangan digital dapat diatasi pemerintah Indonesia dengan memperkuat rencana yang dikenal dengan dengan program MP3EI (Masterplan Percepatan dan Perluasan Pembangunan Ekonomi Indonesia). Salah satu yang menjadi prioritas adalah dengan membangun interconnectivity antara enam koridor ekonomi, yang salah satunya adalah investasi infrastruktur di bidang informasi dan teknologi komunikasi. 


\section{Daftar Pustaka}

Ashburn, E. A., \& Floden, R. E. (2006). Technology, Education-Connections The TEC Series Meaningful Learning Using Technology: What Educators Need to Know and Do Using Technology Wisely: The Keys to Success in Schools.

August, E. G. (2008). Communication Technology Update and Fundamentals.

Carey, J. W. (1989). Communication as Culture.

Daniel, J. S. (2010). Mega-schools, technology and teachers: Achieving education for all. Mega-Schools, Technology and Teachers: Achieving Education for All, 11(3), 1-186. https://doi.org/10.4324/97802038583 25

Green, L. (2010). The Internet: An Introduction to New Media.

Greensdale, R. (2006). new and converging technologies. Hicks: . 'The Media Report', Radio National. Iswanto, R. (2018). Pembelajaran Bahasa Arab dengan Pemanfaatan Teknologi. ARABIYATUNA : Jurnal Bahasa Arab, 1(2). https://doi.org/10.29240/jba.v1i2.286

Konstitusi, B. M. (2003). UU SISdiknas. (1), 6-8. https://doi.org/10.16309/j.cnki.issn.10 07-1776.2003.03.004

Lindhe, L. (1999). "Trends and Predictions."

Marwan, A., \& Sweeney, T. (2010). Teachers' perceptions of educational technology integration in an Indonesian polytechnic. Asia Pacific Journal of Education, 30(4), 463476. https://doi.org/10.1080/02188791.201 0.519554

Mirabito, M. M., \& Morgenstern, B. L. (2004). The new communications technologies : applications, policy, and impact.

Negroponte, N. (1995). Being Digital. 5. Pacey, A. (2013). Review: The Culture of Technology. The MIT Press, 6(1), 13. https://doi.org/10.1086/353712

Richard, T. S. (2012). Sociology a Brief Introduction.

Rogers, E. M. (2003). DIFFUSION OF INNOVATIONS. https://doi.org/10.1007/s10661-0143885-4

Santrock, J. W. (2006). Educational Psychology. Psychological Bulletin, 34(7), 487-490. https://doi.org/10.1037/h0052004

Seels, B., \& Richey, R. C. (1994). Instructional technology: The definition and domains of the field. Association for Educational Communications and Technology, 122.

Stephens, K. K. (2007). The successive use of information and communication technologies at work. Communication Theory, 17(4), 486507. https://doi.org/10.1111/j.14682885.2007.00308.x

Stephens, K. K., \& Rains, S. A. (2011). Information and communication technology sequences and message repetition in interpersonal interaction. Communication Research, 38(1), 101-122. https://doi.org/10.1177/00936502103 62679

Straubhaar, J., LaRose, R., \& Davenport, L. (2012). Understanding Media, Culture, and Technology. Wadsworth, Cengage Learning ALL, Vol 7. 
Widiastuti, T., \& Ruliana, P. (2017).

Narrative Analysis of Marketing

Communication Y2K Music School

and Studio on Social Media. Inter

Komunika: Jurnal Komunikasi, 2(2),

160-171. 